\title{
抗菌性中心静脈カテーテルの臨床的有効性 およびそれによるアナフィラキシー反応
}

光畑裕正*

[要旨］重症患者では中心静脈カテーテル $(C V C)$ によるカテーテル関連血流感染 (catheter-related bloodstream infection : CRBSI)が比較的多くみられ, その 管理は臨床上重要な問題である. クロルヘキシジン/スルファジアジン銀含有 CVC (ARROWgard Blue ${ }^{\circledR}$ Catheters, Arrow International)はカテーテル colonization と CRBSI を有意に減少させる. 頻度は非常に低いものの, 副作用とし てクロルヘキシジンによるアナフィラキシーが報告されている．免疫不全状態にある 重症患者にクロルヘキシジン/スルファジアジン銀含有 CVC を使用するときには， その利益(感染の防御) と不利益(アナフィラキシーの発症)の利益衡量を考え適応を 決定する.

キーワード : 抗菌カテーテル, クロルヘキシジン, アナフィラキシー

(日臨麻会誌 Vol.25 No.7, 637 644, 2005)

\section{はじめに}

現在の診療，とくにICUにおける全身管理におい ては，血管内カテーテルは必要不可欠である。しか し，血管内カテーテルの使用は，患者の局所または 全身感染症の大きな危険因子となっている．血管内 カテーテルの使用頻度では末梢血管に使用するもの が最も多いが，末梢血管でのカテーテルによる感染 の頻度は低い。一方, 重篤なカテーテル関連血流感 染 (catheter-related bloodstream infection : CRBSI) の原因としては中心静脈カテーテル (CVC)によるも のが最も多い。とくに，外来患者や一般的な疾患の 患者に比べて ICUでの全身管理を必要とするような 重症患者に多くみられる。CRBSIを引き起こす微生 物としては，コアグラーゼ陰性ブドウ球菌 (coagulase-negative staphylococci), とくに表皮ブドウ球 菌(staphylococcus epidermidis)が高頻度で分離され ている (表 1) ${ }^{1), 21}$. CVC関連感染は病院感染のなか で重要な要因を占めている，CVCによる感染症の対 策としては，刺入部の十分な消毒，コネクター部の 無菌的管理，刺入時の無菌的操作などが薦められて いる1).

\section{I中心静脈カテーテルによる血流感染}

日本での単純発生率は $0.5 \%$ で, 1.1/1,000CVC/day であり ${ }^{3)}$ ，米国での頻度は $5.3 / 1,000 \mathrm{CVC} / \mathrm{day}$ である 1)。CVCの挿入部位により CRBSIの危険性に違いが ある、鎖骨下静脈への留置が，内頸静脈または大腿 静脈に比べて感染の危険性が低い, あるいは, 内頸 静脈への留置は鎖骨下静脈や大腿静脈に比べて感染 の危険性が高いとの報告がある ${ }^{1)}$ 。しかし，これら の部位間での差異を明確にするだけの慎重な無作為

\footnotetext{
*順天堂大学医学部附属順天堂東京江東 高齢者医療センター麻酔科学・ ペインクリニック教室
}

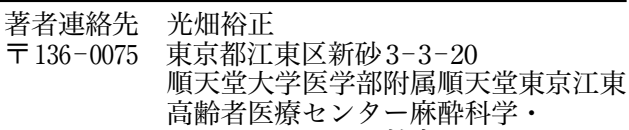


表 1 病院内で発症した血流感染で一般的に分離される微生物

\begin{tabular}{lcc}
\hline & $1986-1989$ & $1992-1999$ \\
微生物 & $\%$ & $\%$ \\
\hline Coagulase-negative staphylococci & 27 & 37 \\
Saureus & 16 & 13 \\
Enterococcus & 8 & 13 \\
Gram-negativerods & 19 & 14 \\
Ecoli & 6 & 2 \\
Enterobacter & 5 & 5 \\
Paeruginosa & 4 & 4 \\
Kpneumoniae & 4 & 3 \\
Candidaspecies & 8 & 8 \\
\hline
\end{tabular}

〔文献1)より引用〕

前向き研究はない. CVCは末梢カテーテルに比べて 感染の危険性が高いので扱入操作時には十分な無菌 的操作が必要である. 実際, $\mathrm{CVC}$ 挿入時に最大無菌 的操作 (帽子，マスク，無菌的術衣，無菌的手袋， 大きな覆布の使用)で施行する場合には, 無菌的手 袋と小さな覆布の使用のみに比べて CRBSI の頻度が 低下する ${ }^{4)}$.

皮膚の消毒に関しては，2\%水溶性グルコン酸ク ロルヘキシジンによる消毒は $10 \%$ ポビドンヨード または70\%アルコールに比べて CRBSIの頻度を低 下させる ${ }^{1)}$. また 8 研究での 4,143 カテーテルのデー 夕を使用したメタ分析でも, 穿刺部位の消毒にクロ ルヘキシジンを用いたときには CRBSIの頻度が $49 \%$ まで低下し，クロルヘキシジンの有効性が明ら かになっている5).

刺入部の管理では透明フィルムドレープや滅菌ガ 一ゼを使用してもCRBSIの頻度には差がない.一方, 刺入部にクロルヘキシジン含有パッチ (Biopatch ${ }^{\mathrm{TM}}$ ) を使用したときはCRBSIの発症頻度が低下すること が多施設研究で明らかにされている ${ }^{1)}$.

またシングルルーメンCVCはマルチルーメン CVCに比べて CRBSIの発症頻度が低いので ${ }^{6)}$, $\mathrm{CVC}$ を選択するときには必要最小限のルーメンの カテーテルを使用する。.さらに抗菌/抗生物質含有 カテーテルの使用により CRBSIの危険性が低下し
ている.

\section{CRBSI に対する抗菌/抗生物質含有カテーテル の有効性}

現在, 抗菌/抗生物質含有カテーテルとしては, クロルヘキシジン/スルファジアジン銀含有カテー テル，ミノサイクリン/レファンピシン含有カテー テル，銀含有カテーテル，レファンピシン/ミコナ ゾール含有カテーテル ${ }^{7}$ などが北米大陸と欧州で使 用されている。梀では，クロルヘキシジン/スル ファジアジン銀含有カテーテルが1995年 10 月から 1997 年 8 月にかけて市販されていたが，このCVC によるアナフィラキシーのため発売が一時中断され ている．抗菌薬や抗生物質がカテーテル材質に含有 されている(コーティングまたは練り込まれている) CVCは CRBSIの危険性を低下させ，このカテーテ ルの価格が一般的な CVCに比べて高いことを考慮 しても ICU管理の重症患者において CRBSIの危険 性を低下させることができれば，カテーテル関連の 感染に対する治療費を結果的に軽減することができ る。抗菌 CVCの有効性に関する研究はすべてトリ プルルーメンカテーテルを用いて，成人で 30 日以 内の留置期間で行われ，その結果米国食品薬品局 (FDA)により体重 $3 \mathrm{~kg}$ 以上の患者に使用することが 承認されている ${ }^{1)}$. 抗菌/抗生物質含有 CVCによる 
表2 抗菌/抗生物質含有中心静脈カテーテルに関する前向き, 無作為の臨床研究のメタ分析結果

\begin{tabular}{|c|c|c|c|c|c|}
\hline カテーテルの含有物質 & 研究数 & $\begin{array}{c}\text { CRBSIの発 } \\
\text { 研究群 } \\
\end{array}$ & $\begin{array}{l}\text { 研究CVC 数 } \\
\text { 対照群 }\end{array}$ & $\mathrm{RR}(95 \% \mathrm{Cl})$ & $\mathrm{p}$ \\
\hline クロルヘキシジン/スルファジァジン銀 & 15 & $68 / 2100$ & $107 / 2135$ & $0.65(0.45-0.90)$ & $<.01$ \\
\hline ミノサイクリンルファンピシン & 1 & $0 / 130$ & $7 / 136$ & $0.00(0.00-2.80)$ & 0.02 \\
\hline \multicolumn{6}{|l|}{ ミノサイクリン/レファンピシン } \\
\hline （対クロルヘキシジン/スルファジアジン銀） & 2 & $1 / 394$ & $14 / 418$ & $0.08(0.00-0.81)$ & $<.01$ \\
\hline 銀 & 4 & $18 / 260$ & $42 / 246$ & $0.40(0.24-0.68)$ & $<.01$ \\
\hline
\end{tabular}

〔文献8)より引用，一部改変〕

CRBSIの発症率に関するメ夕分析の結果を表 2 に示 す ${ }^{8)}$. クロルヘキシジン/スルファジアジン銀含有カ テーテルとミノサイクリン/レファンピシン含有カ テーテル，銀含有カテーテルは有意にCRBSIを減少 させる。

クロルヘキシジン/スルファジアジン銀含有 CVC (ARROWgard Blue ${ }^{\circledR}$ Catheters, Arrow International) は現在まで 10 年以上使用されており，15の無作為 研究により，このCVCがCRBSIを低下させること が明らかになっている ${ }^{8)}$ 。これらの論文の多くが CVCのコロニー形成 (colonization) の頻度を低下さ せることを明らかにしているが，2つの研究のみが CRBSIの発症率の低下を示している ${ }^{9)}$ 10). また, 12 の研究のメ夕分析により, クロルヘキシジン/スル ファジアジン銀含有 CVC は一般的なカテーテルに 比べ有意にカテーテルの colonization と CRBSIの頻 度を低下させ，CRBSIの危険性を少なくとも約 $40 \%$ に低下させることが示されている ${ }^{11)}$. トリプル ルーメンのクロルヘキシジン/スルファジアジン銀 含有 CVCはICU 重症患者を対照にした無作為対照 研究において, グラム陽性球菌と Candida spp.の抑 制によりカテーテルの colonization を有意に抑制し， CRBSIの減少傾向を示した (3.24 vs 2.6/1,000カテー テル/day, $\mathrm{p}=0.79)^{12)}$. このカテーテルの使用によ り CRBSIが $1.2 〜 3.4 \%$ の範囲に減少すれば，死亡率 は $0.09 〜 0.78 \%$ の範囲に減少し，その治療に要する
費用は \$68～\$391の範囲に減少する ${ }^{13)}$.

外側および内腔ともにクロルヘキシジン/スルフ アジアジン銀を含有している新しい C V C (ARROWgard Blue Plus ${ }^{\circledR}$ Catheters, Arrow International)に関する最近の研究では，カテーテル の colonizationを有意に減少させ, 感染を減少させ る傾向にはあるが，CRBSIは減少させなかった。し かし, 感染の危険性が高く, 1〜2週間の CVCの留 置を必要とするICU患者には有効である ${ }^{14)}$.

\section{III 抗生物質含有 CVC}

前向き, 無作為, 多施設研究により，ミノサイク リンルファンピシン含有カテーテルは, クロルヘ キシジン/スルファジアジン銀含有 CVC に比較して colonization $1 / 3$ に減少させ，CRBSI の頻度を $1 / 2$ に減少させた。 7 日目までは両カテーテルのCRBSI に対する有効性は同様であるが，それ以後はミノサ イクリン/レファンピシン含有カテーテルがより有 効である ${ }^{15)}$. 一方, ミノサイクリン/レファンピシ ン含有カテーテルの有用性を検討した前向き, 無作 為, 二重盲検, 対照, 多施設研究では, 本カテーテ ルはコアグラーゼ陰性ブドウ球菌と Candida spp.の colonizationの増加を有意に抑制したが，CRBSIの 減少は認められなかった ${ }^{16)}$ 。ミノサイクリン/レフ アンピシン含有カテーテルとクロルヘキシジン/ス ルファジアジン銀含有 CVCの比較では, 前向き, 
無作為, 多施設研究での 738 カーテルのデータを 使用したメタ分析の結果, 平均 1 週間の留置期間で はCRBSIの頻度はミノサイクリン/レファンピシン 含有カテーテルがクロルヘキシジン/スルファジア ジン銀含有 CVCに比べて有意に低かった ${ }^{15}$. 一方, 平均 6 日間の留置でのミノサイクリン/レファンピ シン含有カテーテルとクロルヘキシジン/スルファ ジアジン銀含有 CVCを比較した無作為対照研究で は, カテーテルの colonization はミノサイクリン/レ ファンピシン含有カテーテルがクロルヘキシジン/ スルファジアジン銀含有 CVCに比べて低い傾向を 示したが，有意ではなかった ${ }^{17)}$. 理論的には，ミノ サイクリン/レファンピシン含有カテーテルはその 耐性菌に対しては効果がなく, また, 而性菌の惹起, 過敏性反応などが考えられるが，2005年 7 月現在ま ではこのような症例は報告されていない ${ }^{8)}$.

\section{IV クロルヘキシジン/スルファジアジン銀含有 CVC によるアナフィラキシー}

クロルヘキシジン/スルファジアジン銀含有 CVC の副作用としては，クロルヘキシジンによるアナフ イラキシーが報告されている.

クロルヘキシジン/スルファジアジン銀含有 CVC によるアナフィラキシーが1997年, 日本で初めて報 告された。本カテーテルには消毒薬のクロルヘキシ ジンが含有されているため, クロルヘキシジンにア レルギーのある患者，またはクロルヘキシジンによ り感作されている可能性のある患者に使用すればア ナフィラキシー反応を起こす。

クロルヘキシジンは 1954 年から医療および日常 生活物質に殺菌薬として広く使用され始め, 現在ま で非常に有用な殺菌薬として, 医療用のみならず一 般的な家庭薬や化粧品, 家庭用品などに広く使用さ れている。クロルヘキシジンによるアレルギー反応 の報告は1962年に初めてアレルギー性接触性皮膚炎 が報告され ${ }^{18)}$ ，アナフィラキシーは1984年に Nishioka ${ }^{19)}$ ，また1986年にOhtoshi らにより日本
で初めて報告されている ${ }^{20)}$. クロルヘキシジンによ るアナフィラキシーの発生頻度は低いと考えられて いるが，頻度は不明である。最近は増加傾向がある とされている ${ }^{21)}$. 前述したように化粧品や歯磨き粉, うがい薬, 入浴剤, 目薬, 手指クリーム (オロナイ ン ${ }^{\circledR} \mathrm{H}$ 軟膏) などの日常生活用品に非常に多く使用さ れているため感作の機会が多いと推測される。クロ ルヘキシジンによるアナフィラキシーの報告数の検 索では 1966 年から 2004年での MEDLINE検索で50 編の論文を，1983 年から 2004 年の医学中央雑誌 Web版で 52 編の日本での報告を検索することがで きた。世界での約 40 年間，日本での約 20 年間とい う期間で計 102 編の報告がみられたことになる。そ の使用頻度とアナフィラキシーの報告数を考えれ ば，クロルヘキシジンによるアナフイラキシー発症 頻度はかなり低いものと推測される。臨床でのクロ ルヘキシジンによるアナフィラキシーは，クロルヘ キシジンの鼻腔粘膜や結膜粘膜, 手術創, 尿道への 接触時，クロルヘキシジン浴などのときに報告され ている.

クロルヘキシジンによるアナフィラキシー発症症 例では，クロルヘキシジンによる非特異的な軽度の 反応や接触性皮膚炎(紅潮, 軽度な薣麻疹, 掻痒)な ぞがショック発症に先行していることが多いた め $^{22) \sim 26)}$ ，クロルヘキシジン/スルファジアジン銀含 有 CVCを使用するときにはクロルヘキシジンを含 む殺菌薬や消毒薬でのアレルギー反応の既往歴を十 分に確認することが望ましい.

クロルヘキシジン/スルファジアジン銀含有 CVC は日本では 1995 年 10 月から 1997 年 8 月まで市販さ れており，117,896本が出荷されていた。その間, アナフィラキシーと推測できる症例が報告され，厚 生省は平成 9 年 8 月「緊急安全情報」により，13例 のアナフィラキシー(アナフィラキシー様反応を含 む)の症例を公表した。13症例の検討によりアナフ イラキシーと検査で確認されたものが 4 症例, 推測 されたものが 2 症例の計 6 症例がアナフィラキシー 
表3 ARROWgard Blue ${ }^{\circledR}$ Catheters (Arrow International) によるアナフィラキシー

\begin{tabular}{lccl}
\hline \multicolumn{1}{c}{ 報告者 } & 報告数 & 確定検査 & 出典 \\
\hline 日本 & & & \\
二階堂祥子ら & 2 & 1症例はパッチテスト, 1 症例は推定 & 麻酔47 : 330-334, 1998 \\
OdaT,etal. & 1 & (prick test) & Anesthesiology87: 1242-1244, 1997 \\
TerazawaE & 1 & skin test & Anesthesiology89: 1296-1298, 1998 \\
$\begin{array}{l}\text { 田中陽子ら } \\
\text { 英国 }\end{array}$ & 1 & DLST & 第34 回日本麻酔学会中国・四国地方会抄録集, 21, 1997 \\
$\begin{array}{lll}\text { PittawayA,etal. } \\
\text { StephensR,etal. }\end{array}$ & 1 & prick test & \\
ニュージーランド & 1 & prick test & BrJAnaesth88 : 304-305, 2002 \\
KlugerM & 1 & BrJAnaesth87 : 306-308, 2001 \\
\hline
\end{tabular}

表4 ARROWgard Blue ${ }^{\circledR}$ Catheters (Arrow International) によるアナフィラキシー症例の症状および所見 〔文献的に報告されている8症例(表3)のまとめ〕

頻度

挿入から発症までの時間：1〜10分

急激な血圧低下から循環虚脱

$100 \%(8 / 8)$

心停止

$13 \%(1 / 8)$

頻脈

$100 \%(7 / 7)$

局所的浮腫、発赤、紅斑、膨疹または

$75 \%(6 / 8)$ 全身性萇麻疹

気管支痙攣

$38 \%(3 / 8)$

と考えられている。このデータから考えられるアナ フィラキシーの発症頻度は $0.005 \%$ と推定できる. また，全世界で発売されているクロルヘキシジン/ スルファジアジン銀含有 $\mathrm{CVC}$ の本数と, アナフィ ラキシーが疑われると報告されている 20 症例数か ら推定できるアナフィラキシーの割合は，1/415,000 $(0.0002 \%)$ とされている(私信)。この 20 症例はアナ フィラキシーの確定検査がすべて行われているので はなく, 実際の発症頻度はさらに低いと推測される。 文献的に報告されている症例を表了に示す。日本で 5 症例，英国で 2 症例，ニュージーランドの 1 症例の 計 8 症例が報告されている。

クロルヘキシジン/スルファジアジン銀含有 CVC のアナフィラキシー8症例の症状・所見を表 4 に示 す. CVC挿入後早期に急激な循環虚脱を示し, 全身
性の莖麻疹・紅斑が高頻度でみられる。一般的な静 注薬物によるアナフィラキシーの症状・所見と同様 である ${ }^{27)}$. CVC挿入直後に急激な循環虚脱がみられ たときには，急性冠症候群，気胸，空気塞栓，ほか の薬物によるアナフィラキシーまたはアナフィラキ シー様反応を鑑別する必要がある.

クロルヘキシジン/スルファジアジン銀含有 CVC によるアナフィラキシーが推測されるときにはクロ ルヘキシジンによるin vivoおよび in vitro検査を行 う。麻酔中であれば使用したすべての薬物 ${ }^{28)}$ ，とく に最もアナフィラキシー/アナフィラキシー様反応 の頻度が高い筋弛緩薬 ${ }^{27)}$ とラテックス ${ }^{25)} も$ 含めた 検査を行う。in vivo検查としては皮膚試験を行 う20),22), 29).プリックテストではクロルヘキシジン $0.5 \%$ 溶液を使用し, 皮内試験では偽陽性が出ない 最小希釈濃度である $0.0002 \%(0.02 \mathrm{~m} l)$ を使用する。 重篤なアナフィラキシーショック症例では $0.005 \%$ 〜 $0.0005 \%$ 溶液を使用してプリックテストを行う。 原因薬物の同定のためのin vitro 検査としては，放射 性免疫吸着試験 (radioallergosorbent test : RAST) に より特異 $\operatorname{IgE}$ 抗体を同定する。細胞性免疫の観点か らの非侵襲的な検査としては，一般的に末梢血から 分離した白血球の培養により行われている。比較的 簡便に行うことができる検査としては，好塩基球脱 顆粒試験, リンパ球ヒスタミン遊離試験, 細胞抗原 刺激試験 $(\mathrm{CAST})$, リンパ球芽球化試験などが薦め 
られている．検査法の詳しい内容は本稿の範囲を超 えているため成書を参照されたい.

\section{まとめ}

クロルヘキシジン/スルファジアジン銀含有 CVC (ARROWgard Blue ${ }^{\circledR}$ Catheters) はカテーテルの colonization と CRBSI を有意に減少させ，ICUでの全身 管理を必要とする重症患者でのCRBSI対策には有効 なカテーテルである. しかし, このカテーテルに使 用されているクロルヘキシジンによるアナフィラキ シーは頻度が低いものの発症の可能性は常に念頭に おく必要がある。クロルヘキシジン/スルファジア ジン銀含有 CVCによるアナフィラキシーが一度発 症すると短時間 (数分以内) に増悪するような急激な 循環抑制(心停止)がみられるため, 十分な注意が必 要であり, 使用前でのアレルギー性接触性皮膚炎の 既往歴の確認を行う。同定のための検査は in vitro 検 査と皮膚試験が薦められる。短期間の CVC 留置を 必要とする免疫不全状態にある重症患者にクロルヘ キシジン/スルファジアジン銀含有 CVCを使用する ときには, その利益(感染の防御) と不利益(アナフ イラキシーの発症)の利益衡量を考え適応を決定す る.

アナフィラキシー症例がありましたら，お教えく ださい(mituhata@lares.dti.ne.jp).

本稿の要旨は, 日本臨床麻酔学会第 24 回大会 (2004年, 大阪)イブニングセミナーにおいて発表した.

\section{参考文献}

1) O'Grady NP, Alexander M, Dellinger EP, et al. : Guidelines for the prevention of intravascular catheter -related infections. Centers for Disease Control and Prevention. MMWR Recomm Rep 51:1-29, 2002

2) Ferretti G, Mandala M, Di Cosimo S, et al. : Catheterrelated bloodstream infections, part II : specific pathogens and prevention. Cancer Control 10: 79-91, 2003
3）大久保憲，大原永子，中村明茂ほか：4. 血管内留置力 テーテルの管理。日外会誌 105：705-708，2004

4) Hu KK, Veenstra DL, Lipsky BA, et al.: Use of maximal sterile barriers during central venous catheter insertion : clinical and economic outcomes. Clin Infect Dis 39 : 1441-1445, 2004

5) Chaiyakunapruk N, Veenstra DL, Lipsky BA, et al. Vascular catheter site care : the clinical and economic benefits of chlorhexidine gluconate compared with povidone iodine. Clin Infect Dis 37 : 764-771, 2003

6) Zurcher M, Tramer MR, Walder B: Colonization and bloodstream infection with single-versus multi-lumen central venous catheters: a quantitative systematic review. Anesth Analg 99 : 177-182, 2004

7) Rump AF, Guttler K, Konig DP, et al.: Pharmacokinetics of the antimicrobial agents rifampicin and miconazole released from a loaded central venous catheter. J Hosp Infect 53: 129-135, 2003

8) Crnich CJ, Maki DG: The promise of novel technology for the prevention of intravascular device-related bloodstream infection. I. Pathogenesis and short-term devices. Clin Infect Dis $34: 1232-1242,2002$

9) Hanley EM, Veeder A, Smith T, et al. : Evaluation of an antiseptic triple-lumen catheter in an intensive care unit. Crit Care Med 28:366-370, 2000

10) Maki DG, Stolz SM, Wheeler S, et al.: Prevention of central venous catheter-related bloodstream infection by use of an antiseptic-impregnated catheter. A randomized, controlled trial. Ann Intern Med 127 : 257266, 1997

11) Veenstra DL, Saint S, Saha S, et al. : Efficacy of antiseptic-impregnated central venous catheters in preventing catheter-related bloodstream infection: a meta-analysis. JAMA 281 : 261-267, 1999

12) Carrasco MN, Bueno A, de las Cuevas C, et al.: Evaluation of a triple-lumen central venous heparincoated catheter versus a catheter coated with chlorhexidine and silver sulfadiazine in critically ill patients. Intensive Care Med 30 : 633-638, 2004

13) Veenstra DL, Saint S, Sullivan SD: Cost-effectiveness of antiseptic-impregnated central venous catheters for the prevention of catheter-related bloodstream infection. JAMA 282: 554-560, 1999

14) Brun-Buisson C, Doyon F, Sollet JP, et al.: Prevention of intravascular catheter-related infection with newer chlorhexidine-silver sulfadiazine-coated catheters: a randomized controlled trial. Intensive Care Med 30: 837-843, 2004

15) Darouiche RO, Raad II, Heard SO, et al. : A comparison 
of two antimicrobial-impregnated central venous catheters. Catheter Study Group. N Engl J Med 340 : 1 $-8,1999$

16) Leon C, Ruiz-Santana S, Rello J, et al.: Benefits of minocycline and rifampin-impregnated central venous catheters. A prospective, randomized, double-blind, controlled, multicenter trial. Intensive Care Med 30 : 1891-1899, 2004

17) Marik PE, Abraham G, Careau P, et al.: The ex vivo antimicrobial activity and colonization rate of two antimicrobial-bonded central venous catheters. Crit Care Med 27 : 1128-1131, 1999

18) Calnan CD : Contact dermatitis from drugs. Proc R Soc Med 55 : 39-42, 1962

19) Nishioka K, Doi T, Katayama I: Histamine release in contact urticaria. Contact Dermatitis $11: 191,1984$

20) Ohtoshi T, Yamauchi N, Tadokoro K, et al. : IgE antibody-mediated shock reaction caused by topical application of chlorhexidine. Clin Allergy 16: 155-161, 1986

21) Krautheim AB, Jermann TH, Bircher AJ : Chlorhexidine anaphylaxis : case report and review of the literature. Contact Dermatitis 50: 113-116, 2004

22) Garvey LH, Roed-Petersen J, Husum B: Anaphylactic reactions in anaesthetised patients-four cases of chlorhexidine allergy. Acta Anaesthesiol Scand 45 : 1290-1294, 2001
23) Ebo DG, Stevens WJ, Bridts CH, et al. : Contact allergic dermatitis and life-threatening anaphylaxis to chlorhexidine. J Allergy Clin Immunol 101: 128-129, 1998

24) Wicki J, Deluze C, Cirafici L, et al. : Anaphylactic shock induced by intraurethral use of chlorhexidine. Allergy 54: 768-769, 1999

25) Porter BJ, Acharya U, Ormerod AD, et al. : Latex/chlorhexidine-induced anaphylaxis in pregnancy. Allergy 53 : 455-457, 1998

26) Pham NH, Weiner JM, Reisner GS, et al. : Anaphylaxis to chlorhexidine. Case report. Implication of immunoglobulin $\mathrm{E}$ antibodies and identification of an allergenic determinant. Clin Exp Allergy 30: 10011007,2000

27) Mertes PM, Laxenaire MC, Alla F: Anaphylactic and anaphylactoid reactions occurring during anesthesia in France in 1999-2000. Anesthesiology 99: 536-545, 2003

28) Thong BY, Yeow C: Anaphylaxis during surgical and interventional procedures. Ann Allergy Asthma Immunol 92: 619-628, 2004

29) Beaudouin E, Kanny G, Morisset M, et al.: Immediate hypersensitivity to chlorhexidine: literature review. Allerg Immunol(Paris) 36 : 123-126, 2004 


\title{
Clinical Effectiveness of Antimicrobial-Impregnated Central Venous Catheter and Anaphylaxis Induced by the Catheter
}

\author{
Hiromasa MITSUHATA \\ Department of Anesthesiology and Pain Medicine, Juntendou Tokyo Koto Geriatric Medical Center
}

The majority of catheter-related bloodstream infections (CRBSI) are associated with central venous catheter in serious patients. The CRBSI is an important issue for the control of infection in hospitals. The use of catheters coated on the external surface with chlorhexidine/silver sulfadiazine (ARROWgard Blue ${ }^{\circledast}$ Catheters, Arrow international) significantly reduced the risk for catheter colonization and CR-BSI compared with standard noncoated catheters. Although rare, anaphylaxis has been reported with the use of these chlorhexidine/silver sulfadiazine catheters, and a patient allergic to chlorhexidine should not be exposed to chlorhexidine/silver sulfadiazine-impregnated catheters. The actual risk of anaphylaxis is likely quite small with the estimated prevalence of $0.005 \%$ or $1 / 415,000(0.0002 \%)$. Concern has been expressed with regard to the potential risk (anaphylaxis), but the catheter should be effective to reduce CRBSI in patients who need central venous catheter in ICU.

Key Words : Antiseptic-impregnated catheter, Catheter related infection, Anaphylaxis

The Journal of Japan Society for Clinical Anesthesia Vol.25 No.7, 2005 